\title{
The Effect of Tuftsin on the Nitrous Blue Tetrazolium Reduction of Normal Human Polymorphonuclear Leukocytes
}

\author{
Z. Spirer, V. Zakuth, A. Golander, N. Bogair, and M. Fridkin \\ From the Pediatrics Department " $A$ ", and the Immunological Unit, Hadassah \\ Hospital, Governmental-Municipal Medical Center, Tel-Aviv University \\ Medical School, Tel-Aviv, and the Department of Organic Chemistry, \\ Weizmann Institute of Science, Rehovot, Israel
}

A в S T RAC T The influence of Tuftsin, the synthetic phagocytosis-stimulating tetrapeptide (L-threonyl-L-lysylL-prolyl-L-arginine), on the nitrous blue tetrazolium (NBT) reduction by human polymorphonuclear leukocytes was investigated. It was found that this substance increases the NBT reduction by approximately as much as endotoxin. Other tetrapeptides do not share this property. When Tuftsin analogs are added to the cell suspension and incubated, they prevent the action of both Tuftsin and endotoxin but not of methylene blue. When washed of the analogs, the cells regain the property to be activated by both Tuftsin and endotoxin. It appears that methylene blue on one hand and Tuftsin and endotoxin on the other hand have different sites for their actions. We suggest that whereas methylene blue diffuses into the cell and acts directly upon the hexosemonophosphate shunt activation, Tuftsin and endotoxin appear to act on the cell membrane binding to specific receptors. By treating the cells with Tuftsin analogs, we probably block these receptors.

\section{INTRODUCTION}

Fidalgo and Najjar demonstrated in 1967 (1) the presence in dog sera of a specific "leukophilic" gamma globulin that can bind to autologous leukocytes and stimulates their phagocytic activity against pathogenic Staphylococcus aureus. Several reports have since appeared indicating the importance of this fraction in man. It was named leukokinin, and its action was well documented $(2-4)$.

Najjar and Nishioka (3) showed that the phagocytosis-stimulating effect of leukokinin is due to a single peptide fragment, liberated from the globulin by leuko-

Dr. Spirer's address is: P. O. Box 51, Tel-Aviv, Israel. Received for publication 28 June 1974 and in revised form 6 September 1974. kininase, a specific enzyme of the outer membrane of the neutrophil. This peptide was isolated, and its amino acid sequence was shown to be L-threonyl-L-lysyl-I.prolyl-L-arginine. It was named Tuftsin (3). Recently it was synthesized (5), and the biological action of this tetrapeptide was ascertained. Since the sera of splenectomized men $(6)$ and dogs $(7,8)$ lack the stimulating effect of Tuftsin, it has been suggested that the spleen is the site of its production. Tuftsin acts in hormonelike quantities. In addition to enhancing particle ingestion, such as bacteria and latex, it also stimulates pinocytosis of radiolabeled albumin and enhances the motility and migration of polymorphonuclear leukocytes $(\mathrm{PMN})^{1}(5)$.

Published reports on Tuftsin have dealt with its effect on the phagocytic activity of the leukocyte. No reference whatever has been made to its possible influence on the bactericidal activity of the leukocyte. As reduction of nitrous blue tetrazolium (NBT) (9-11) is a well-known method of study of at least one important aspect of this bactericidal activity, we have investigated the effect of Tuftsin upon this process in human PMN.

\section{METHODS}

Preparation of Tuftsin and analog. Tuftsin (L-threonylL-lysyl-L-prolyl-L-arginine) was synthesized by two different methods $^{2}$ : in steps with dicyclohexylcarbodiimide as a coupling agent (12), and in steps with the polymeric-reagents approach (13). Both preparations were found to be identical and pure when analyzed by techniques such as elemental analysis, amino acid analysis, electrophoresis, and chromatography with various solvent systems. Both preparations showed identical biological activity.

Des'-threonyl-Tuftsin, alanyl ${ }^{4}$-Tuftsin, and W-nitro-Tuftsin were prepared by the polymeric reagents approach (13).

${ }^{1}$ Abbreviations used in this paper: analog 1, DES' threonyl-Tuftsin; analog 2, alanyl ${ }^{4}$ Tuftsin; NBT, nitrous blue tetrazolium; PMN, polymorphonuclear leukocytes.

${ }^{2}$ Detailed synthetic procedures will be published elsewhere. 
Oligolysines (kindly donated by Dr. A. Yaron) were prepared by the solid-phase peptide approach (14).

The quantitative NBT reduction test. 25-ml samples of venous blood, donated by healthy young medical students, were collected in $30-\mathrm{ml}$ disposable plastic tubes containing $50 \mathrm{U}$ heparin/ml (Organon Inc., West Orange, N. J.). All samples were processed immediately after the venipuncture. $5 \mathrm{ml}$ of $6 \%$ dextran (Fluka A. G., Basel, Switzerland) solution were added to each tube, and the mixture was allowed to settle for $1 \mathrm{~h}$ at room temperature. The next steps were strictly as described by Bachner and Nathan (9) with the following modifications:

Experiment 1. To test tubes with $0.1 \mathrm{ml}$ of a leukocyte suspension (approximately $2.5 \times 10^{8}$ leukocytes, with a viability index of at least $95 \%$ ) we added instead of latex particles one of the following materials : $20 \mu \mathrm{g}$ of endotoxin (Difco Laboratories, Detroit, Mich.) (B, lipopolysaccharide) $(0.2 \mathrm{ml}) ; 0.1 \mu \mathrm{g}$ of Tuftsin $(0.1 \mathrm{ml}) ; 0.1 \mu \mathrm{g}$ of Tuftsin $\mathrm{NO}_{2}(0.1 \mathrm{ml}) ; 0.1 \mu \mathrm{g}$ of analog $1(0.1 \mathrm{ml}) ; 0.1$ $\mu \mathrm{g}$ of analog $2(0.1 \mathrm{ml}) ; 0.1 \mu \mathrm{g}$ lysine $4(0.1 \mathrm{ml}) ; 0.22 \mathrm{mmol}$ of methylene blue (BDH Chemicals Ltd., Poole, England); $20 \mu \mathrm{g}$ of endotoxin $(0.2 \mathrm{ml})+0.1 \mu \mathrm{g}$ Tuftsin $(0.1 \mathrm{ml})$. All the above substances were dissolved in sterile phosphatebuffered saline, $\mathrm{pH}$ 7.4. After addition of $0.1 \mathrm{ml}$ of $0.1 \%$ NBT (Sigma Chemical Co., Inc., St. Louis, Mo.) to each tube, the mixtures were incubated for $30 \mathrm{~min}$ at $37^{\circ} \mathrm{C}$. The reaction was stopped by addition of $10 \mathrm{ml} 0.5 \mathrm{~N} \mathrm{HCl}$ and centrifuged. The reduced NBT (formazan) was extracted in $3 \mathrm{ml}$ pyridine (BDH Chemicals Ltd.) under a boiling water bath. The color intensity of the pyridine was determined in a Unicam 800 spectrophotometer (Unicam Instruments Ltd., Cambridge, England). Results were expressed as $\triangle \mathrm{OD}$ of reduced NBT in $2.5 \times 10^{\circ}$ cells $/ 30 \mathrm{~min}$ (calculated as the difference in OD between stimulated tubes and blanks). All reagents were prepared under strictly sterile conditions with Millipore filters (Millipore Corp., Bedford, Mass.) to avoid any particulate matter that might stimulate phagocytosis.

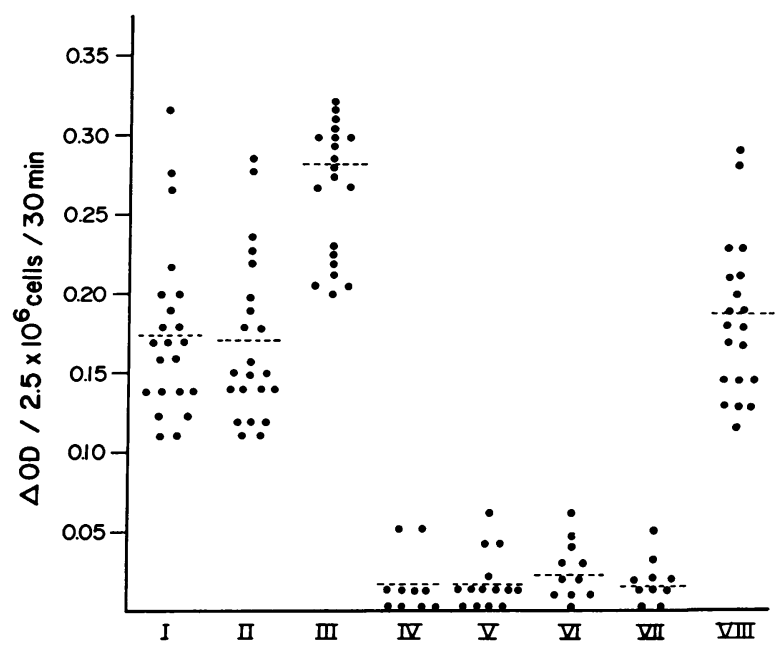

FIGURE 1 Differences in optical density $(\Delta O D)$ between stimulating and resting NBT reduction tests with the following stimulators: I, Tuftsin; II, endotoxin; III, methylene blue; IV, oligolysin; V, Tuftsin $\mathrm{NO}_{2}$; VI, analog 1; VII, analog 2; VIII, endotoxin plus Tuftsin. The dotted lines indicate the mean values for each experimental protocol.
TABLE I

Results of Experiment 2

\begin{tabular}{|c|c|c|c|c|c|}
\hline \multirow{2}{*}{$\begin{array}{c}\text { Pre- } \\
\text { incubated }\end{array}$} & \multirow[b]{2}{*}{ Stimulus } & \multirow{2}{*}{$\begin{array}{l}\text { No. of } \\
\text { tests }\end{array}$} & \multicolumn{3}{|c|}{$\Delta O D$} \\
\hline & & & Mean & SD & Range \\
\hline \multirow[t]{4}{*}{ Analog 1} & Tuftsin & 11 & 0.030 & 0.021 & $0.00-0.050$ \\
\hline & Endotoxin & 10 & 0.027 & 0.024 & $0.00-0.060$ \\
\hline & Methylene & 8 & 025 & 006 & \\
\hline & & & 0.20 & .00 & $0.10-0.01$ \\
\hline \multirow{3}{*}{ Analog 2} & Tuftsin & 11 & 0.028 & 0.020 & $0.00-0.05$ \\
\hline & $\begin{array}{l}\text { Endotoxin } \\
\text { Methylene }\end{array}$ & 10 & 0.031 & 0.022 & $0.00-0.05$ \\
\hline & blue & 8 & 0.25 & 0.05 & $0.15-0.37$ \\
\hline
\end{tabular}

$\triangle O D$, difference in optical density between NBT reduced by resting and stimulated cells preincubated with analog 1 and analog 2 .

Experiment 2. The same cell suspensions as in experiment 1 were preincubated for $5 \mathrm{~min}$ at room temperature with $0.1 \mu \mathrm{g}$ of Tuftsin analogs 1 and 2 , respectively. To the test tubes we added separately: $0.1 \mu \mathrm{g}$ Tuftsin; $20 \mu \mathrm{g}$ endotoxin; $0.22 \mathrm{mmol}$ methylene blue and $0.1 \mathrm{ml}$ of $0.1 \%$ NBT. The $\triangle O D$ in experiment 2 was calculated as in experiment 1.

Experiment 3. Cell suspensions, incubated as above with Tuftsin analogs 1 and 2 , were washed three times with a Krebs-Ringer solution. Tuftsin $(0.1 \mu \mathrm{g})$ and endotoxin (20 $\mu \mathrm{g}$ ), respectively, and NBT were then added to the suspension, and $\triangle O D$ was calculated.

\section{RESULTS}

Fig. 1 demonstrates the distribution of $\triangle O D$ calculated from experiment 1 . It shows clearly that Tuftsin acts in all suspensions of live leukocytes to the same degree as endotoxin, $0.177 \pm 0.055$ and $0.171 \pm 0.053$, respectively, and less than methylene blue $(0.28 \pm 0.062)$. Tuftsin $\mathrm{NO}_{2}$, Lysine, analog 1 , and analog 2 act weakly (low $\Delta \mathrm{OD})$ on the stimulation of the NBT reduction and have a similar range of values: $0.014,0.016,0.023$, and 0.016 , respectively, without statistical difference between them. Simultaneous addition of endotoxin and Tuftsin gives results as for Tuftsin alone, $0.180 \pm 0.050$.

Table I summarizes the results of experiment 2 . It shows that Tuftsin analogs 1 and 2 , when added to the cell suspension and incubated, prevent the increase of the NBT reduction by both Tuftsin and endotoxin. They do not prevent the activation by methylene blue. There is no difference between these analogs in this inhibitory effect on the NBT reduction.

Experiment 3 revealed that when washed of the analogs, the cells regain the capacity to be activated by both Tuftsin and endotoxin (values similar to in experiment $1, \Delta \mathrm{OD} 0.175$ and 0.170 , respectively). 


\section{DISCUSSION}

The increase in the percentage of NBT-reducing leukocytes and of the total reduced dye is due to the activation of the hexosemonophosphate shunt (15). This can be induced theoretically either by increased phagocytosis, as in latex-stimulated cells (9), or by such direct activators as methylene blue, which acts without enhancing the phagocytic action (16).

We have shown that Tuftsin acts like endotoxin. The effects of both can be prevented by blocking agents such as the Tuftsin analogs. When these are removed, the cells recover their reactivity to both Tuftsin and endotoxin. The effect of methylene blue, on the other hand, is not blocked by the analogs. The effect of blocking was previously demonstrated by Najjar and Constanopoulos (6), using a synthetic Tuftsin analog and a natural pathological inactive Tuftsin molecule found in a familial disorder of Tuftsin production.

Recent observations indicate that NBT is phagocytized by the cell as a complex (with fibrinogen and/or heparin) (17). Whether Tuftsin acts as a stimulator of this phagocytosis or in some unknown way as a direct activator of the hexosemonophosphate shunt is not indicated by our experiments.

The influence of Tuftsin on $\mathrm{CO}_{2}$ production by the hexosemonophosphate shunt activation is now under our investigation. This study will, we hope, resolve these contradictions. But whatever is the mode of action, our present observations confirm Najjar's conclusion that the simple tetrapeptide is an active substance and binds, probably by specific receptors, to the membrane of humoral PMNs.

\section{REFERENCES}

1. Fidalgo, B. V., and V. A. Najjar. 1967. The physiological role of the lymphoid system. III. Leukophilic $\gamma$ globulin and the phagocytic activity of the polymorphonuclear leukocyte. Proc. Natl. Acad. Sci. U. S. A. 57 : 957-964.

2. Fidalgo, B. V., and V. A. Najjar. 1967. The physiological role of the lymphoid system. VI. The stimulatory effect of leukophilic gamma-globulin (leucokinin) on the phagocytic activity of human polymorphonuclear leukocyte. Biochemistry. 6: 3386-3392.

3. Najjar, V. A., and K. Nishioka. 1970. Tuftsin: a natural phagocytosis-stimulating peptide. Nature (Lond.). 228: 672-673.

4. Constantopoulos, A., V. A. Najjar, and J. W. Smith. 1972. Tuftsin deficiency: a new syndrome with defective phagocytosis. J. Pediatr. 80: 564-572.

5. Nishioka, K., A. Constantopoulos, P. S. Satoh, and V. A. Najjar. 1972. The characteristics, isolation and synthesis of the phagocytosis-stimulating peptide Tuftsin. Biochem. Biophys. Res. Commun. 47: 172-179.

6. Najjar, V. A., and A. Constantopoulos. 1972. A new phagocytosis-stimulating tetrapeptide hormone, Tuftsin, and its role in disease. J. Reticuloendothel. Soc. 12: 197215.

7. Najjar, V. A., B. V. Fidalgo, and E. Stitt. 1968. The physiological role of the lymphoid system. VII. The disappearance of leukokinin activity following splenectomy. Biochemistry. $7:$ 2376-2379.

8. Constantopoulos, A., V. A. Najjar, and J. B. Wish. 1973. Defective phagocytosis due to Tuftsin deficiency in splenectomized subjects. Am. J. Dis. Child. 125: 663665.

9. Baehner, R. L., and D. G. Nathan. 1968. Quantitative nitroblue tetrazolium reduction test in chronic granulomatous disease. N. Engl. J. Med. 278: 971-976.

10. Park, B. H., S. M. Fikrig, and E. M. Smithwick. 1968. Infection and nitroblue tetrazolium reduction by neutrophils : a diagnostic aid. Lancet. 2: 532-534.

11. Park, B. H., and R. H. Good. 1970. N.B.T. test stimulated. Lancet. 2 : 616

12. Sheehan, J. C., and G. P. Hess. 1955. A new method of forming peptide bonds. J. Am. Chem. Soc. 77: 1067.

13. Patchornik, A., M. Fridkin, and E. Katchalski. 1973. Use of polymeric reagents in the synthesis of linear and cyclic peptides. In The Chemistry of Polypeptides. P. G. Katsoyannis, editor. Plenum Publishing Corporation, New York. 315-333.

14. Merrifield, R. B. 1969. Solid-phase peptide synthesis. Adv. Enzymol. Relat. Areas Mol Biol. 32: 221-296.

15. Humbert, J. R., G. P. Gross, A. E. Vatter, and W. E. Hathaway. 1973. Nitroblue tetrazolium reduction by neutrophils. Biochemical and ultrastructural effects of methylene blue. J. Lab. Clin. Med. 82: 20-30.

16. Karnovsky, M. 1968. The metabolism of leukocytes. Semin. Hematol. 5 : 156-165.

17. Segal, A. W., and A. J. Levy. 1973. The mechanism of the entry of dye into neutrophils in the nitroblue tetrazolium (NBT) test. Clin. Sci. Mol. Med. 45: 817826. 